\title{
Mire Development and Disappearance due to River Capture as Hydrogeological and Geomorphological Consequences of LGM Ice-Marginal Valley Evolution at the Vistula-Neman Watershed
}

\author{
Grzegorz Wierzbicki ${ }^{1, *}$, Mateusz Grygoruk ${ }^{1}$ (D), Maria Grodzka-Łukaszewska ${ }^{2}$ (), Piotr Bartold ${ }^{1}$ \\ and Tomasz Okruszko ${ }^{1}$ \\ 1 Institute of Environmental Engineering, Warsaw University of Life Sciences SGGW-WULS, \\ ul. Nowoursynowska 166, 02-787 Warsaw, Poland; mateusz_grygoruk@sggw.edu.pl (M.G.); \\ piotr_bartold@sggw.edu.pl (P.B.); tomasz_okruszko@sggw.edu.pl (T.O.) \\ 2 Faculty of Building Services, Hydro and Environmental Engineering, Warsaw University of Technology, \\ ul. Nowowiejska 20, 00-653 Warsaw, Poland; maria.grodzka@pw.edu.pl \\ * Correspondence: grzegorz_wierzbicki@sggw.edu.pl; Tel.: +48-22-59-35-237
}

Received: 30 June 2020; Accepted: 7 September 2020; Published: 11 September 2020

\begin{abstract}
The advances and retreats of ice sheets during Pleistocene significantly changed highand mid-latitude landscapes and hydrological systems, albeit differently, in North America and Europe. On the southern margin of the Last Glacial Maximum (LGM) in the Baltic Sea basin, a specific type of valley has developed between glacial margins and upland or mountain slopes. We studied new geological data (boreholes, electrical resistivity imaging (ERI) from this geomorphic setting in Northeast Poland to understand: (1) how the landscape and river network evolved to eventually produce peat mires during the Holocene, and (2) the nature of groundwater recharge to fens in the upper Biebrza Valley. We present the results on a geological cross-section with hydrogeological interpretation. We also discuss regional geomorphology. In addition, we present the LGM extent derived from a spatial distribution of Vistulian (Weichselian) terminal moraines. These end moraines are also interpreted as Saalian kames. Thus, we additionally present another method of LGM extent delineation from a physicogeographical division. We link the steep slopes of the studied valley walls (kame terrace fronts) with thermokarst erosion in the periglacial zone. We then document the hydrogeological window (DISCONTINUITY in the till layer over the confined aquifer), which enables the outflow of groundwater into the peat bog. Although minerotrophic fen mire development in the study area is likely to be sustained in the near future through sufficient groundwater supply, the projected capture of the Biebrza River by the Neman River will not allow for sustaining peatland development.
\end{abstract}

Keywords: wetland; fluvioglacial; glaciofluvial; ice lobe; bifurcation; Belarus; Lithuania

\section{Introduction}

In stark contrast to the Laurentide Ice Sheet in North America, the Fennoscandian Ice Sheet had to advance upslope its southern margin in response to the higher topography of Middle Europe [1-4] (Figure 3A and Figure 3A). As a result, many ice-dammed lakes appeared along the LGM extent in Germany, Poland, the Baltic States and Northwest Russia [1] and the proglacial river network there underwent significant changes [2]. These changes include the involved development of wide (as much as $25-30 \mathrm{~km}$ ) valleys parallel to the margin of the ice sheet. The valleys were oriented latitudinally, and their slope dropped westerly. Thus, they conveyed water from the middle of 
continent towards the Atlantic Ocean through the English Channel (in French: Fleuve Manche) paleoriver and the Celtic Sea [2]. The valleys collected an enormous volume of water from both southward-flowing glacial meltwater (emanating from parts of Lithuania, Latvia and Estonia, as well as southern Finland) and northward streamflow from rivers in ice-free areas (uplands and mountains) in southern Germany and Poland (Figure 3A and Figure 3A). This type of large valley trending parallel to the margin of an ice sheet is called "Urstromtal" in German and "pradolina" in Polish. The literal translation of the Polish term is "ancient valley", but it was once erroneously translated into English as "ice-marginal valley". Moreover, the term has slightly different meanings in North America and New Zealand [5].

The system of ice-marginal valleys in the study area has evolved significantly since the LGM. It probably experienced catastrophic glacial-outburst megafloods [6], the latter retreat of the Fennoscandian Ice Sheet and a subsequent postglacial rebound: a glacial isostatic adjustment (GIA) [2,7-10]. The last stage of its evolution occurred in the Holocene. This is when the high saturation of the superficial layers of valley sediments—coupled with the favorable climate-allowed for the development of mires. Unique hydrogeological features and suspected hydrogeological windows are responsible for supplying the Upper Basin of the Biebrza Valley with mineral-rich groundwater [11-13] However, due to the architectural complexity of fluvioglacial sediments, these hydrogeological windows-that supply distantly recharged groundwater to topographic depressions-are seldom documented.

In this paper, we present new geological data collected in an ice-marginal valley in the southeastern sector of the Fennoscandian Ice Sheet during the LGM to achieve the following: (1) understand the evolution of the hydrological system that resulted in the formation of a large and relatively homogeneous minerotrophic fen mire, and (2) determine the groundwater recharge of mires in one of the largest coherent protected areas of fens in Europe.

\section{Study Area}

The study area is a reach of the ice-marginal valley presently occupied by the upper Biebrza and Nurka Rivers in Northeast Poland near the border with Belarus and Lithuania (Figure 3). The study area is also the combined watershed of the Vistula and Neman (Belarusian: Нёман; Lithuanian: Nemunas; Polish: Niemen) Rivers, which is the second-largest catchment in the Baltic Sea basin.

\section{Materials and Methods}

Four new boreholes, as deep as $20 \mathrm{~m}$, were drilled to determine the sediment lithology and the Quaternary stratigraphy. These boreholes were situated along the transect, perpendicular to the valley in the study area (Figure 3C). We supplemented the borehole logs with electrical resistivity imaging (ERI). ERI data were gathered through seven cross-sections parallel to the line of the boreholes (Figure 3C). In our interpretation of the data derived from the boreholes and from the ERI, we follow 1:50,000-scale [14,15] and 1:250,000-scale [16] geological maps.

We placed emphasis on the LGM extent in northeast Poland due to its significance in the landscape evolution in the study area. For this reason, we performed a geospatial analysis of existing 1:50,000-scale geologic maps $[17,18]$. On the basis of end-moraine till outcrops $[17,18]$, we redrew the maximum extent of ice during the LGM, extending it from eastern Poland into Belarus [19].

We also drew the old, but most widely accepted, line representing the maximum extent of ice during the LGM in Poland. The line origins from the geomorphological division of Poland (and adjacent parts of neighboring countries) into physical units defined by a similar landscape type [20,21]. The LGM extent can be derived from [20] as a boundary between (a) lakeland (young glacial high plains) and (b) old glacial high plains without lakes. Geomorphological delineation there is based [20] on the "fresh" and distinct imprint left by ice sheets in the landscape within the extent of LGM, namely a dominance of concave landforms filled by lakes and usually surrounded by morainic hills. Areas located beyond the LGM are specified by the old glacial landscape: a lack of lakes, a lack of clear depressions (remnants of paleolakes) and a slighter (flatter) relief of morainic hills. Such a 
landscape resulted from the periglacial transformation of young glacial landforms during the last glaciation period, cf. [22] the Eemian paleolakeland of the Radom Plain in central Poland, an iconic example of the Polish old glacial landscape. We juxtaposed both the old and the redrawn ice margins with the digital elevation model (DEM), extending them eastward into adjacent Belarus and northward into Lithuania (Figure 3B). The DEM was derived from the shuttle radar topography mission (SRTM). We used ArcMap for geospatial data processing and AutoCAD for drawing the geological cross-section.

We juxtaposed both the old and the redrawn ice margins with the digital elevation model (DEM), extending them eastward into adjacent Belarus and northward into Lithuania (Figure 3B). The DEM was derived from the shuttle radar topography mission (SRTM). We used ArcMap for geospatial data processing and AutoCAD for drawing the geological cross-section.

\section{Results}

\subsection{Local Geological Setting}

Our geological cross-section (Figure 1) summarizes quaternary stratigraphy in the study area. Lithostratigraphic logs of boreholes are presented as Supplementary Material to this manuscript. Peat stratum (Figure 1(7)), as much as $7 \mathrm{~m}$ in thickness, fills in the entire valley bottom. Both sides of the valley consist of kame terraces (Figure 1(6)) formed during the last glaciation (Vistulian; from German also: Weichselian). One of the kame terraces on the northern edge of the valley sits atop glacial tills from an older glaciation (Saalian; Figure 1(4)).

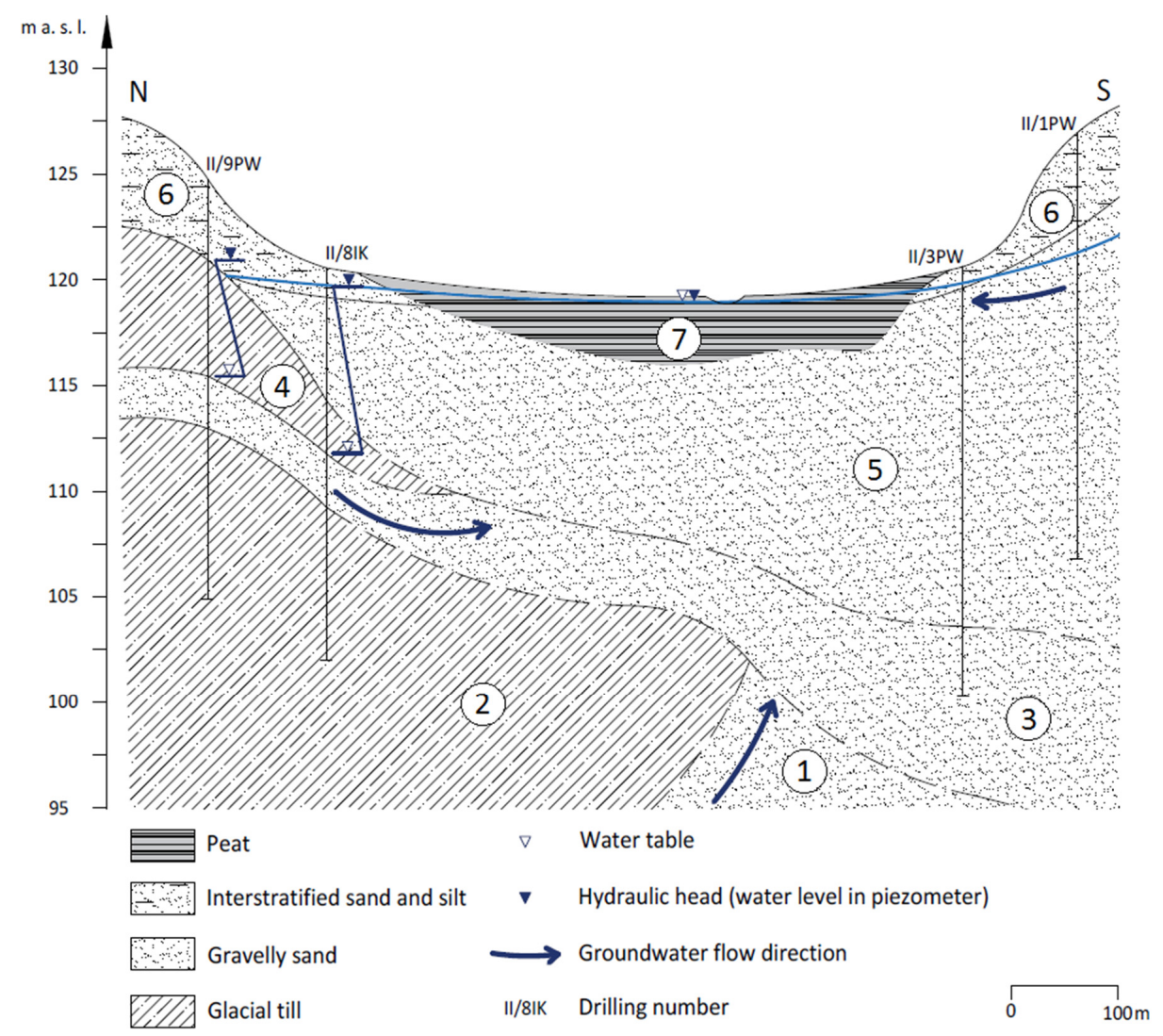

Figure 1. Geological cross-section through the Upper Biebrza ice-marginal valley (Vistula river catchment, NE Poland). Stratigraphy and genetic type of deposits: 1-Saalian (Odra) fluvioglacial sediments; 2-Saalian (Odra) glacial sediments 3-Saalian (Warta) fluvioglacial sediments; 4-Saalian (Warta) glacial sediments; 5-Vistulian (pre-LGM) fluvioglacial sediments; 6-Vistulian (post-LGM) kame terrace; 7 -Holocene peat. 
The boreholes did not penetrate the glacial tills under the southern valley edge; thus, the southern kame terrace was deposited atop the fluvioglacial sediments (Figure 1(5)). Together, the kame terrace and the underlying sands and gravels make up a sequence of fluvioglacial deposits exceeding $20 \mathrm{~m}$ in aggregate thickness. We recognize three subunits in this sequence: (i) the overlying kame terrace, (Figure 1(6)); (ii) a middle subunit (Figure 1(5)) dating to the last glaciation (Vistulian) and attaining $10 \mathrm{~m}$ in maximum thickness in the ice-marginal valley; and (ii) an old subunit (Figure 1(3)) that was deposited during the Saalian period. This Saalian (Warta) layer of fluvioglacial sediments (Figure 1(3)) is deposited atop an older Saalian (Odra) tills (Figure 1(2)) under the northern edge of the valley. The lack of any glacial tills under peats (Figure 1(7)) enables a recharge of mires by groundwater (Figure 1, blue arrows) coming from confined aquifers (Figure 1(3) and possibly Figure 1(1)).

\subsection{Regional Geological Setting}

The study area was glaciated during the LGM. Our new rendering of the LGM margin assumes a lobate shape (Figure 3B-LGM extent in geology), which is a typical pattern left in the landscape by a glacial lob, especially a surging ice lob-for example, the late glacial lobes of the Laurentide Ice Sheet in the USA (Des Moines Lobe in Iowa [23,24], James Lobe in South Dakota and Nebraska [24] and the Huron-Erie Lobe in Ohio and Indiana [23]; the re-advance of the LIS in Southeast Alberta (Canada) [25]; or the ice streams flowing downslope from a glacial dome (e.g., in the central sector of the British-Irish Ice Sheet [26]).

The LGM margin can be delineated in two ways depending on the criteria (geomorphology vs. surficial geology) employed (Figure 3B). If it is determined solely on the basis of geology, the LGM ice margin is $25-35 \mathrm{~km}$ south of its position determined strictly by geomorphology [20,21].

The present upper Biebrza River in the study area is a small remnant of the large hydrological system that drained the Fennoscandian Ice Sheet (Figure 3A; Figure 2A). The upper Biebrza River appears to be underfit relative to the width of its valley, suggesting that the latter was formed during a time of a significantly higher discharge. The river occupies a relict late Pleistocene ice-marginal valley (Figures $3 \mathrm{~A}$ and $2 \mathrm{~B}, \mathrm{C}$ ). The inherited landform is hundreds of times larger than the present-day river channel is (which is just $2-4 \mathrm{~m}$ in width).

The headwaters of the upper Biebrza River are very close to the Neman River (Figure 3B), which has a valley that corresponds to the size of the river itself. The Neman River valley has a typical riverine floodplain, four levels of terraces [16] and a channel deeply incised into Pleistocene glacial and fluvioglacial sediments. The water table in the Neman River is $30-40 \mathrm{~m}$ lower than the water table in the study area is. Furthermore, the straight-line distance from the study area across the drainage divide and the Neman River to the base level of the Baltic Sea is three times shorter through the drainage divide and the Neman River compared with the present confluent course of the Biebrza, Narew and lower Vistula Rivers. 


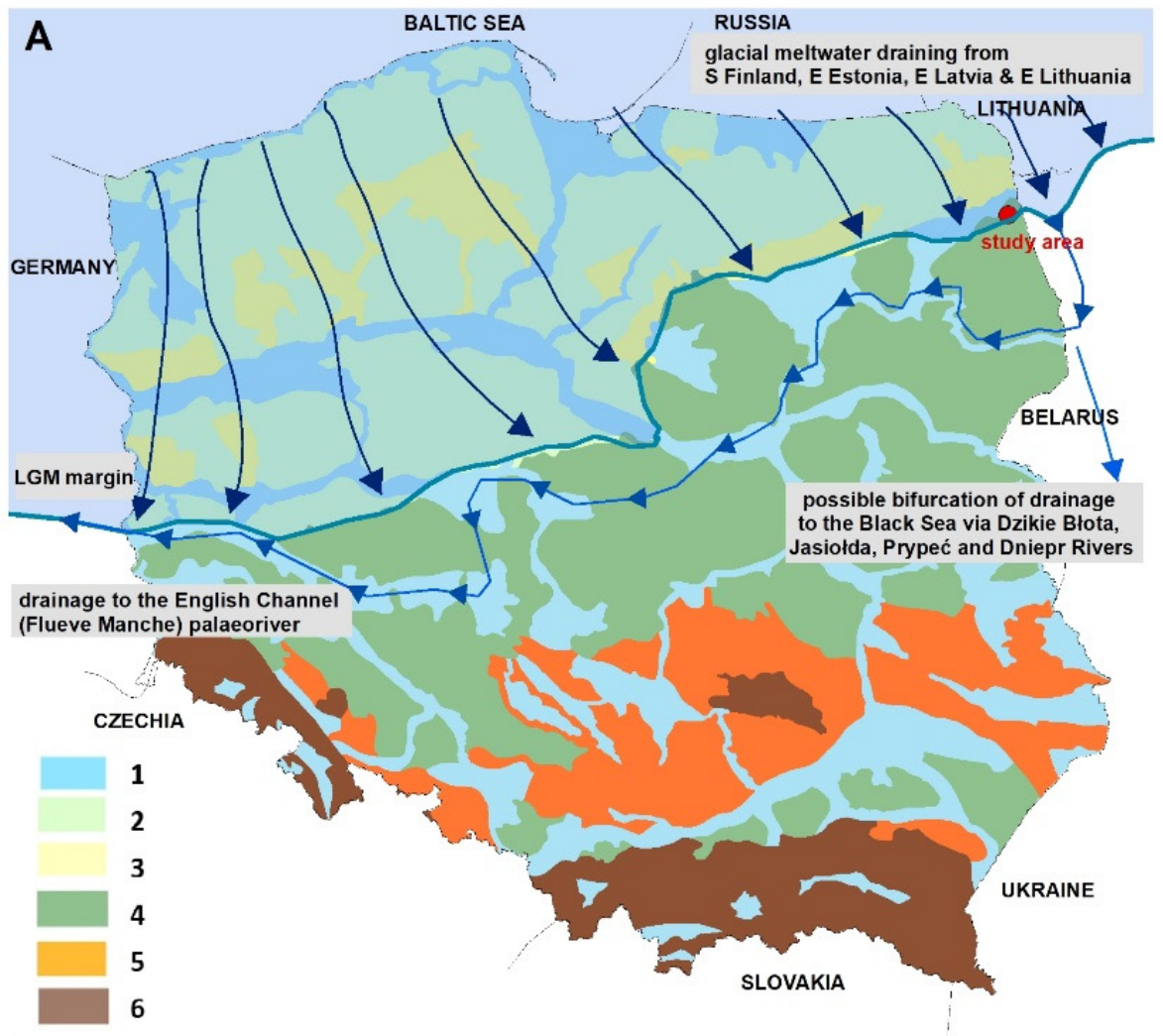

Source: Kondracki and Richling 1994 (Atlas of Republic of Poland) $0 \quad 50 \quad 100 \quad 200$ km

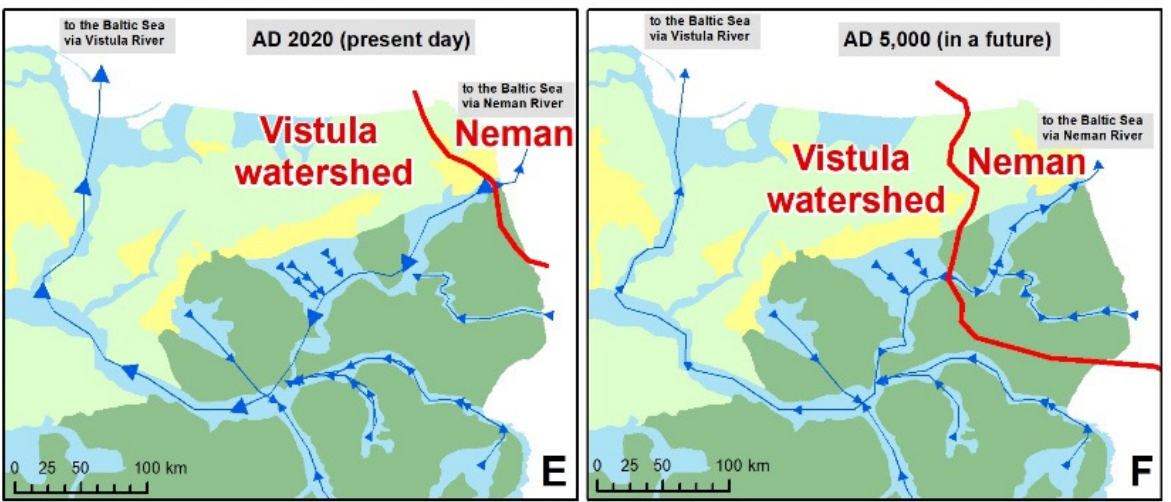

Figure 2. Evolution of hydrological system in Southeast sector of Baltic Sea basin during (A) LGM (possibly asynchronous in Poland, referenced to Świecie stadial in the study area [16,19]; (B) main (Leszno) stadial; (C) recessive (Poznań) stadial; (D) recessive (Gardno) stadial; (E) present day; (F) in the future. Description of colors-types of landscape [20]: 1-large river valleys, ice marginal valleys, wide tectonic or melt-out depressions; 2-lakeland, glacial (young) high plains in the LGM extent; 3-sandurs and outwash plains in the LGM extent; 4-old glacial (Saalian and older) high plains beyond the LGM extent; 5-upland; 6-mountains (Carpathians, Sudetes, Holly Cross Mountains) and their piedmonts. 


\section{Discussion and Insights}

\subsection{Extent of the Last Glacial Maximum in Northeastern Poland}

The LGM margin, which we have newly delineated via a spatial analysis of the outcrops of glacial sediments on the geological maps [17,18] (Figure 3B), is not delineated on the regional geological map on a coarser scale [16], published later using the same data. The LGM end moraines (Figure 3B, black crosses) depicted on the finer-scale maps [17,18] were interpreted on the coarser-scale map [16] as completely different glacial landforms, namely kames (the outcrop caption on the map is "sands, silts, gravels and tills of kames"). Moreover, Marks and Karabanov [16] assigned an older-than-Vistulian age to these landforms_-Saalian (Warta Stadial in Poland, Soż Stadial in Belarus) —and drew them on the cross-section [16] as kame terraces developed in the Sidra River Valley (Figure 3B). Thus, Marks and Karabanov [16] rendered the LGM margin in a geographic position similar to that which was determined separately on the basis of geomorphology [20,21].

Wrotek [18,27] emphasized that these isolated landforms are so high (usually $>200 \mathrm{~m}$ ASL) that at least six of them (Góra Basielowa, Góra Sygnały, Góra Łokietka, Góra Solniczka, Wólczańskie Góry, Karpackie Góry; Figure 3B, black crosses) are actually called "mountain" (góra, pl. góry) in Polish. Kozłowski [17] and Wrotek [18] drew these LGM end moraines on a geological cross-section as hills (10-30 m high; built on Vistulian glacial till, sand and gravel) sitting atop the Saalian morainic plateau, which is built on glacial till only. A 1:50,000-scale map that encompasses the study area $[17,18,27,28]$ emphasizes that the local landscape around LGM end moraines (Figure 3B) is similar to the landscape that was undoubtedly glaciated in the Vistulian age. However, one significant difference exists—a lack of lakes [28].

A discussion of the genesis (terminal moraines vs. kames) and the age (Vistulian vs. Saalian) of these landforms must be supported by further field study on the internal structures of these hills. A kame is usually defined as a landform of fluvioglacial (glaciofluvial) [29] or glaciolacustrine genesis [30]. A stratification should appear in the kame as a result of sedimentation in an environment dominated by deposition in water. Sediment stratification also proves to be useful for distinguishing a kame from a terminal moraine, which is deposited directly from active glacial ice.

Benn and Evans [29] emphasized that the term of kame is used in several senses in the literature, which sometimes makes it confusing. In the recently published papers (describing present-day glacial environments in various locations on Earth), the term "kame" is usually associated with the word "kettle" [25,31,32], or "terrace" [33-37]. The "kame and kettle" terms always describe the hummocky topography of an area larger than a single landform [29]. In fact, "kame and kettle topography" is actually a type of landscape where tracts of kames intervene in kettle holes (concave landforms) [29]. "Kame terrace" is a type of terrace deposited by glacial meltwater on the valley side-between the glacier (or ice sheet) margin and the valley wall [29]. We also followed this definition in the study (Figure 1(6)). Other recently published papers [30,38-44] indicate that kame is an isolated hill (or a plateau [29] that used to be a specific feature of the Polish lowlands landscape beyond the LGM extent (the area ice-modeled by Saalian glaciation and by older glaciations). Generally, most isolated hills located between parallel belts of end-moraines in northern and central Poland used to be called kames [45].

A decades-long debate of the extent of the LGM in northeast Poland [19,46-48] will probably continue in the future. However, the existence of kame terraces on both valley edges in the present study area (Figure 1(6)) implies that the ice-marginal valley was covered by an active ice lobe or by dead ice from a retreating ice sheet during the last glaciation. These landforms (Figure 1(6)) date back to the Vistulian glaciation on maps on both scales: a finer one [14,15,49] and a coarser one [16]. 


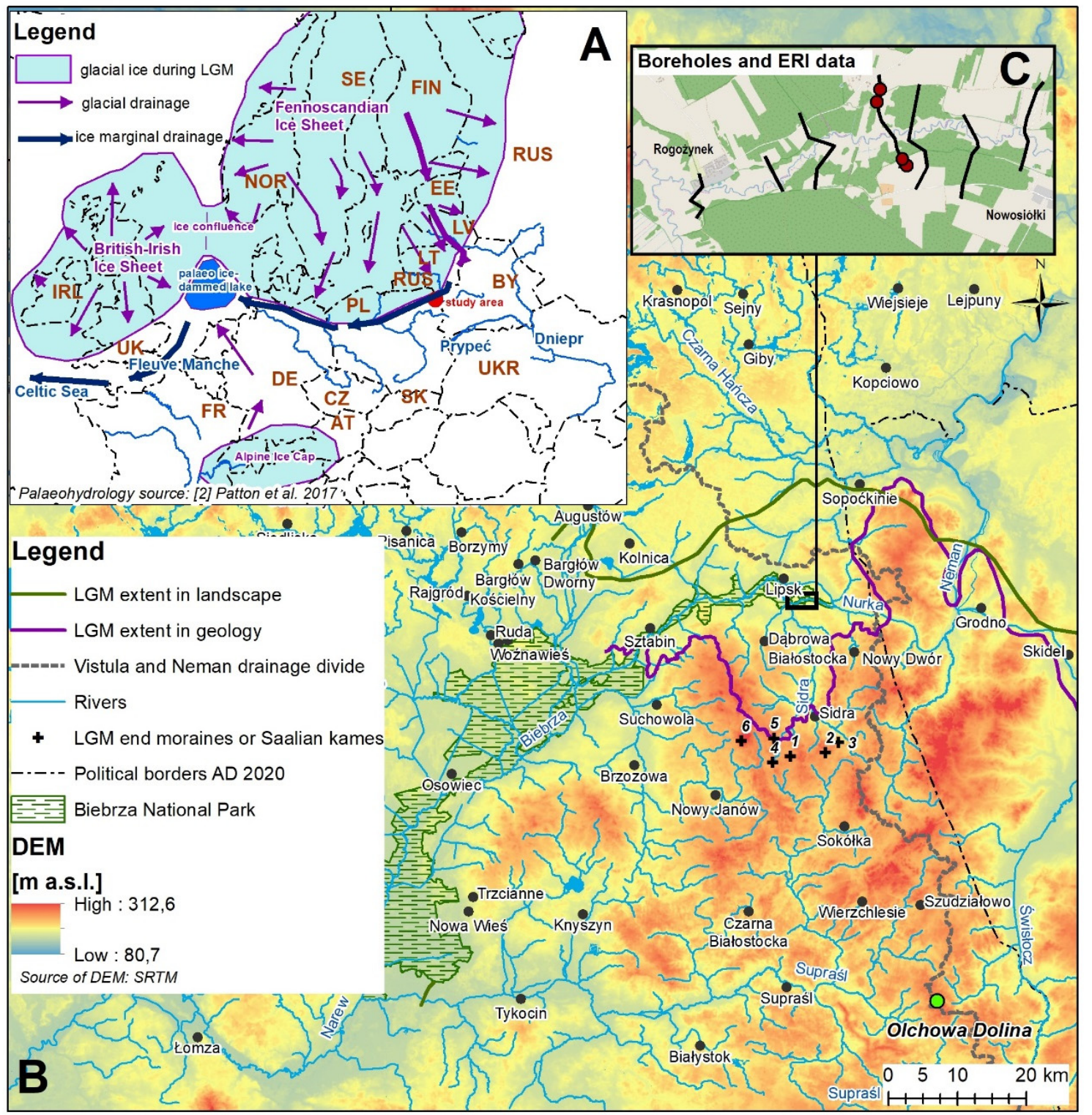

Figure 3. Study area. (A) Location on political map of Europe with paleohydrological setting during LGM [2]; (B) location on digital elevation model (DEM)-shuttle radar topography mission (SRTM) of NE Poland and adjacent parts of Lithuania and Belarus. LGM extent derived from: (i) landscape division (green line) [20,21], (ii) outcrops of Vistulian glacial till (purple line) $[17,18,49]$ in Poland and [19] in Belarus. Black crosses are LGM terminal moraines [17,18,49] or Saalian kames [16]: 1—Góra Basielowa (218.2 m ASL), 2-Góra Sygnały (214.1 m ASL), 3-Góra Łokietka (191.2 m ASL), 4-Góra Sotniczka (192.6 m ASL), 5-Wólczańskie Góry (213 m ASL), 6-Karpackie Góry (229.2 m ASL); (C) location of boreholes (red dots) and ERI profiles (black lines) in the Upper Biebrza valley between Rogożynek (Lipsk Municipality, Augustów County) and Nowosiółki (Nowy Dwór Municipality, Sokółka County) settlements on OpenStreetMap.

\subsection{Post-Pleistocene Evolution of Regional Hydrology}

Hydrological systems in the Northern Hemisphere evolved after the LGM [2], and the present study area exhibits evidence of significant changes in surface-water features (Figure 2A-D). Because the study area was covered by the Fennoscandian Ice Sheet during the LGM (Figures 3 and 2A), we assume that glacial draining meltwater could not flow through the studied valley reach, as the ice-marginal valley had yet to form. It was just completely covered by the glacial ice. Under these conditions, meltwater 
originating from a $300,000 \mathrm{~km}^{2}$ catchment [2] had to find a route around the Sokółka Hills [20,21,50] and Grodno Highland [51]. To identify such an alternative meltwater course, we searched for local depressions on the present Vistula and Neman drainage divide south of the study area. We found two possible routes:

(I) Olchowa Dolina (Figure 3B) between the Supraśl River and the Świsłocz River. In this area, a relatively small ( $2 \mathrm{~km}$ long and $100-200 \mathrm{~m}$ wide) valley exists. The valley is dry (cf. [50]) and lies between a bog to the east, drained by the Świsłocz River tributary and another to the west, which is drained by the Supraśl River. The floor of this dry valley (elevation $\sim 160 \mathrm{~m}$ ASL) lies approximately $30 \mathrm{~m}$ above the surfaces of the two adjacent peatlands. We interpret this valley as a remnant of possible paleo-bifurcation between Pra-Vistula and Pra-Neman drainage systems because of its location, its east-west orientation and its specific shape, which is similar to that of the fluvial valley. The high elevation of the valley can be interpreted by postglacial rebound only, but such an interpretation is usually difficult to prove with clear evidence [2].

Consider (II) Dzikie Błota (in Belarussian: Дзікае балота) between the present-day springs of the Narew (Vistula River tributary), Jasiołda (Prypeć River tributary) and Roś (Neman River tributary) Rivers (Figures 3A and 2A). Dzikie Błota complex is located in Belarus between the towns of Wołkowysk and Kobryń.

A Belarussian geomorphological map [52] presents an ancient valley there (from Belarusian: Древнія Доліна) that crosses the present-day continental divide of the Baltic and Black Seas. The valley marked on the map [52] is the largest one ( $80 \mathrm{~km}$ long and $15 \mathrm{~km}$ wide) among such valley landforms in Belarus. Peat fills its bottom in. The elevation of the Roś and Narew watershed area is $\sim 145 \mathrm{~m}$ ASL The map [52] indicates an outwash plain between the spring of Roś River and the edge of the Narew-Jasiołda ancient valley.The highest points on these two possible meltwater courses well exceed the elevation of the LGM subglacial paleo-surface in comparison with the elevation of the Skidel ice-dammed lake (120 m ASL), which received meltwater from the Fennoscandian Ice Sheet [51,53]. Therefore, the valleys cannot transmit throughflow in the present topographical setting. Still, they could do this in a different setting before the postglacial rebound (GIA, cf. [2,7-10]). Accordingly, we interpret them as late Pleistocene fluvial landforms. Further field study is needed here.

Shortly after the LGM, the Fennoscandian Ice Sheet retreated and stopped at the Main Stadial (Figure 2B). We hypothesize that kame terraces (Figure 1(6)) were formed in the study area at that time (Figure 2B). Simultaneously, the Neman-Biebrza ice-marginal valley functioned as the main route for glacial meltwater and proglacial water from the gradually draining Skidel ice-dammed lake $[51,53]$. Fluvioglacial (kame) accumulation between glacial ice and the valley edges (valley walls) was the dominating process in the study area. During the first recessive stadial (Figure 2C), when the Torun-Eberswlade ice-marginal valley in western Poland [5] captured all of the glacial draining system from northeast Poland and the eastern Baltic States (as well as water flowing from ice-free areas), the study area was impacted by erosion. The erosion could have resulted from glacial outburst flood events [6], but we speculate that it occurred progressively as a result of thermokarstic processes [54-56]. The study area was thus located in a periglacial environment. Permafrost (not be confused with glacial ice or blocks of dead ice [57]) was widespread in the study area $[58,59]$. The edges (walls) of the ice-marginal valley were shaped by retrogressive thaw slumping controlled by insolation as in modern Siberia [60]. This hypothesis is consistent with the steepness of the valley walls, which, consisting of loose sand, could be eroded to steeper angles if they were frozen at the time.

Erosion remained active during the second recessive stadial (Figure 2D). The erosional impact of glacial outburst floods were realized completely. We hypothesize that retrogressive thaw slumping driven by insolation remained a dominant process. As a result of lower discharge in the valley, erosion stopped on the valley edges, but it continued as an incision at the valley bottom. However, the river erosion rate estimated from stream power ("available [also gross] stream power" per unit length [61] and "specific stream power" per unit channel width [62]) had to be very small at that time due to the dimensions of the inherited valley: low river slope and high valley width. Erosion driven by water 
flow is not possible with such a low river slope. Deposition occurs in such conditions (cf. [63] a similar calculation of stream power in the lower Vistula River during an extreme flood in 2010).

\subsection{Evolution of Hydrological System in the Holocene, Nowadays and in Future}

The eastern part of the ice-marginal valley-now occupied by the Popilija (Pripilija) River in Belarus (Figure 3B, prolongation of the Nurka River to the east) - was captured by the Neman River and a new watershed between the Vistula River and Neman River was formed (Figure 2E) in the Holocene. The outlet of the Biebrza ice-marginal valley to the west (into the Narew River) was dammed by dunes and by isostatic uplift $[2,64]$. A limited outflow in the broad valley induced the stagnancy of water, which later resulted in peat formation (Figure 1(7)). We regard peat formation as the dominant process in the study area during the entire Holocene period. However, our hydrogeological interpretation of the cross-section (Figure 1, blue arrows) suggests that groundwater recharges the wetland as well.

We propose that the combined Vistula-Neman watershed will eventually extend beyond the Biebrza ice-marginal valley. Thereafter, a new watershed will probably develop in a narrow reach of the Narew River valley located next to Łomża (Figures 3B and 2F). The water level in the Narew River there is $\sim 95 \mathrm{~m}$ ASL-15 $\mathrm{m}$ higher than in the Neman River in south Lithuania. As a result, the entire Upper Narew River-including its anastomosing reach [65]—will be captured by the Neman River as well.

On the basis of our results, we hypothesize that the mires in the Upper Basin of the Biebrza Valley will cease to exist in the near geologic future. Along with a number of changes in hydrological regime that are expected to occur as a result of climatic change and land management of the area [66] we hypothesize that a series of other changes will occur in the following sequence: (1) The vast elevation differences between the Biebrza and Neman Rivers-as well as the predicted evolution of the hydrological system of the area-will redirect the flow from the present upper Narew River through the Biebrza River and towards the Neman River, a new watershed; (2) A gradual decrease in flooding in the present lower Biebrza Basin will occur due to the reduction of catchment areas; (3) An onset of relatively stable hydrological conditions in the middle Biebrza Basin will occur-along with the quick drainage of groundwater from the Upper Basin of the Biebrza Valley towards the Neman River. Furthermore, this scenario is likely to result in the eventual ombrotrophication of peatlands in the lower Biebrza Basin due to the establishment of a new watershed as well as the reconfiguration of the groundwater flow paths accompanying the lowering of the base level in the Neman River.

Supplementary Materials: The following are available online at http://www.mdpi.com/2076-3263/10/9/363/s1, Raw boreholes data are included in the supplementary data for this manuscript.

Author Contributions: G.W. and M.G. developed a concept of the paper. G.W., M.G.-Ł. and P.B. prepared figures and interpretation of graphic material in the paper. G.W., M.G. and M.G.-Ł. prepared first draft of the paper. G.W. and M.G. handled revisions of the manuscript. All authors corrected the final proof of the manuscript. All authors have read and agreed to the published version of the manuscript.

Funding: This research was funded by Narodowe Centrum Nauki (The National Science Centre, Poland), grant number 2016/21/B/ST10/03042.

Acknowledgments: We thank Tomasz Falkowski and Łukasz Sopel for geological and hydrogeological consultations. Jan Grygo and Stanisław Grygo supported the first author during field observations in the study area. We kindly acknowledge 3 anonymous reviewers for their thoughtful comments that allowed us to improve the manuscript. We are especially grateful to the reviewer No. 2., who put significant load of work: constructively commented on the former draft of the paper and provided more than 500 corrections.

Conflicts of Interest: The authors declare no conflict of interest.

\section{References}

1. Stroeven, A.P.; Hättestrand, C.; Kleman, J.; Heyman, J.; Fabel, D.; Fredin, O.; Goodfellow, B.W.; Harbor, J.M.; Jansen, J.D.; Olsen, L.; et al. Deglaciation of Fennoscandia. Quat. Sci. Rev. 2016, 147, 91-121. [CrossRef]

2. Patton, H.; Hubbard, A.; Andreassen, K.; Auriac, A.; Whitehouse, P.L.; Stroeven, A.P.; Shackleton, C.; Winsborrow, M.; Heyman, J.; Hall, A.M. Deglaciation of the Eurasian ice sheet complex. Quat. Sci. Rev. 2017, 169, 148-172. [CrossRef] 
3. Dyke, A.S.; Andrews, J.T.; Clark, P.U.; England, J.H.; Miller, G.H.; Shaw, J.; Veillette, J.J. The Laurentide and Innuitian ice sheets during the Last Glacial Maximum. Quat. Sci. Rev. 2002, 21, 9-31. [CrossRef]

4. Marshall, S.J.; James, T.S.; Clarke, G.K.C. North American Ice Sheet reconstructions at the Last Glacial Maximum. Quat. Sci. Rev. 2002, 21, 175-192. [CrossRef]

5. Pisarska-Jamroży, M. Factors controlling sedimentation in the Torun-Eberswalde ice-marginal valley during the Pomeranian phase of the Weichselian glaciation: On overview. Geologos 2015, 21, 1-29. [CrossRef]

6. Weckwerth, P.; Wysota, W.; Piotrowski, J.A.; Adamczyk, A.; Krawiec, A.; Dabrowski, A. Late Weichselian glacier outburst floods in North-Eastern Poland: Landform evidence and palaeohydraulic significance. Earth-Sci. Rev. 2019, 194, 216-233. [CrossRef]

7. Ulomov, V.I.; Akatova, K.N.; Medvedeva, N.S. Estimation of Seismic Hazard in the Kaliningrad Region. Izv. Phys. Solid Earth 2017, 44, 691-705. [CrossRef]

8. Pisarska-Jamrozy, M.; Belzyt, S.; Borner, A.; Hoffmann, G.; Huneke, H.; Kenzler, M.; Obst, K.; Rother, H.; van Loon, A.J. Evidence from seismites for glacio-isostatically induced crustal faulting in front of an advancing land-ice mass (Rugen Island, SW Baltic Sea). Tectonophysics 2018, 745, 338-348. [CrossRef]

9. Pisarska-Jamrozy, M.; Belzyt, S.; Bitinas, A.; Jusiene, A. Seismic shocks, periglacial conditions and glaciotectonics as causes of the deformation of a Pleistocene meandering river succession in central Lithuania. Baltica 2019, 32, 63-77.

10. Steffen, H.; Steffen, R.; Tarasov, L. Modelling of glacially-induced stress changes in Latvia, Lithuania and the Kaliningrad District of Russia. Baltica 2019, 32, 78-90.

11. Oświt, J. Structure, genesis and development of peatlands in the Biebrza Valley. Zeszyty Problemowe Postępów Nauk Rolniczych 1984, 372, 185-217. (In Polish)

12. Pajnowska, H.; Poźniak, R. Hydrogeology of the Biebrza Valley and the surrounding areas. Zeszyty Problemowe Postępów Nauk Rolniczych 1984, 372, 63-74. (In Polish)

13. Żurek, S. Relief, geologic structure and hydrography of the Biebrza Valley. Pol. Ecol. Stud. 1984, 10, $231-259$.

14. Krzywicki, T. Detailed Geological Map of Poland 1:50,000; Sheet 187 Lipsk; PGI: Warszawa, Poland, 2003.

15. Majewska, A. Detailed Geological Map of Poland 1:50,000; Sheet 188 Rygałówka (Sopoćkinie); PGI: Warszawa, Poland, 2007.

16. Marks, L.; Karabanov, A.K. Geological Map 1:250,000 of Polish-Belarusian Cross-Border Area Sokótka and Grodno Region; PGI: Warszawa, Poland, 2011.

17. Kozłowski, I. Detailed Geological Map of Poland 1:50,000; Sheet 224 Suchowola; PGI: Warszawa, Poland, 2003.

18. Wrotek, K. Detailed Geological Map of Poland 1:50,000; Sheet 225 Dabrowa Białostocka; PGI: Warszawa, Poland, 2009.

19. Krzywicki, T. The maximum ice sheet limit of the Vistulian Glaciation in northeastern Poland and neighbouring areas. Geol. Quart. 2002, 46, 165-188.

20. Kondracki, J.; Richling, A. Regiony Ficzycznogeograficzne: Atlas Rzeczypospolitej Polskiej [Physico-Geographical Regions: Atlas of the Republic of Poland]; Map Sheet 53.3; GGK: Warsaw, Poland, 1994.

21. Solon, J.; Borzyszkowski, J.; Bidłasik, M.; Richling, A.; Badora, K.; Balon, J.; Brzezińska-Wójcik, T.; Chabudziński, Ł.; Dobrowolski, R.; Grzegorczyk, I.; et al. Physico-geographical mesoregions of Poland: Verification and adjustment of boundaries on the basis of contemporary spatial data. Geogr. Pol. 2018, 91, 143-170. [CrossRef]

22. Żarski, M.; Winter, H.; Kucharska, M. Palaeoenvironmental and climate changes recorded in the lacustrine sediments of the Eemian Interglacial (MIS 5e) in the Radom Plain (Central Poland). Quat. Int. 2018, 467, 147-160. [CrossRef]

23. McDeid, S.M.; Green, D.I.S.; Crumpton, W.G. Morphology of Drained Upland Depressions on the Des Moines Lobe of Iowa. Wetlands 2019, 39, 587-600. [CrossRef]

24. Margold, M.; Stokes, C.R.; Clark, C.D. Reconciling records of ice streaming and ice margin retreat to produce a palaeogeographic reconstruction of the deglaciation of the Laurentide Ice Sheet. Quat. Sci. Rev. 2018, 189, 1-30. [CrossRef]

25. Evans, D.J.A.; Atkinson, N.; Philips, E. Glacial geomorphology of the Neutral Hills Uplands, southeast Alberta, Canada: The process-form imprints of dynamic ice streams and surging ice lobes. Geomorphology 2020, 350, 106960. [CrossRef] 
26. Davies, B.J.; Livingstone, S.J.; Roberts, D.H.; Evans, D.J.A.; Gheorghiu, D.M.; Cofaigh, C.Ó. Dynamic ice stream retreat in the central sector of the last British-Irish Ice Sheet. Quat. Sci. Rev. 2019, 225, 105989. [CrossRef]

27. Wrotek, K. Objaśnienia do Szczegółowej Mapy Geologicznej Polski, Arkusz 225 Dabrowa Białostocka; PIG: Warszawa, Poland, 2017. Available online: http://bazadata.pgi.gov.pl/data/smgp/arkusze_txt/smgp0225.pdf (accessed on 9 July 2020).

28. Majewska, A. Objaśnienia do Szczegótowej Mapy Geologicznej Polski, Arkusz 226 Nowy Dwór; PIG: Warszawa, Poland, 2007. Available online: http://bazadata.pgi.gov.pl/data/smgp/arkusze_txt/smgp0226.pdf (accessed on 9 July 2020).

29. Benn, D.I.; Evans, D.J.A. Glaciers and Glaciation; Arnold: London, UK, 1998.

30. Gruszka, B.; Terpiłowski, S. Sedimentary Record of the Younger Saalian Ice Margin Stagnation in Eastern Poland. Geogr. Ann. Ser. A Phys. Geogr. 2015, 97, 279-298. [CrossRef]

31. Evans, D.J.A.; Ewertowski, M.; Orton, C. Skaftafellsjokull, Iceland: Glacial geomorphology recording glacier recession since the Little Ice Age. J. Maps 2017, 13, 358-368. [CrossRef]

32. Chandler, B.M.P.; Evans, D.J.A.; Chandler, S.J.P.; Ewertowski, M.W.; Lovell, H.; Roberts, D.H.; Schaefer, M.; Tomczyk, A.M. The glacial landsystem of Fjallsjökull, Iceland: Spatial and temporal evolution of process-form regimes at an active temperate glacier. Geomorphology 2020, 361, 107192. [CrossRef]

33. Barrell, D.J.; Putnam, A.E.; Denton, G.H. Reconciling the onset of deglaciation in the Upper Rangitata valley, Southern Alps, New Zealand. Quat. Sci. Rev. 2019, 203, 141-150. [CrossRef]

34. Davies, B.J.; Thorndycraft, V.R.; Fabel, D.; Martin, J.R.V. Asynchronous glacier dynamics during the Antarctic Cold Reversal in central Patagonia. Quat. Sci. Rev. 2018, 200, 287-312. [CrossRef]

35. Evans, D.J.A.; Ewertowski, M.; Orton, C.; Graham, D.J. The Glacial Geomorphology of the Ice Cap Piedmont Lobe Landsystem of East Mýrdalsjökull, Iceland. Geosciences 2018, 8, 194. [CrossRef]

36. Martin, J.R.V.; Davies, B.J.; Thorndycraft, V.R. Glacier dynamics during a phase of Late Quaternary warming in Patagonia reconstructed from sediment-landform associations. Geomorphology 2019, 337, 111-133. [CrossRef]

37. Sen Singh, D.; Dubey, C.A.; Kumar, D.; Vishawakarma, B.; Singh, A.K.; Tripathi, A.; Gautam, P.K.; Bali, R.; Agarwal, K.K.; Sharma, R. Monsoon variability and major climatic events between 25 and 0.05 ka BP using sedimentary parameters in the Gangotri Glacier region, Garhwal Himalaya, India. Quat. Int. 2019, 507, 148-155. [CrossRef]

38. Wysocka-Czubaszek, A.; Roj-Rojewski, S. Variability of Soil Properties in Eroded Agricultural Landscape. J. Ecol. Eng. 2020, 21, 72-80. [CrossRef]

39. Włodarski, W.; Orłowska, A. Topography and melting dynamics of ice-cored ridges: Evidence from the geometry, kinematics and sedimentary evolution of collapse structures within kame deposits, eastern Poland. Boreas 2019, 48, 891-912. [CrossRef]

40. Kupryjanowicz, M.; Drzymulska, D. Evolution of a small Eemian lake in a unique location on a kame hill: Haćki site, NE Poland. Quat. Int. 2015, 386, 203-207. [CrossRef]

41. Terpiłowski, S. Genesis of transverse kame trains in eastern Poland. Sediment. Geol. 2007, 193, 59-69. [CrossRef]

42. Godlewska, A.; Terpiłowski, S. Transverse, supraglacially derived crevasse infillings in a Pleistocene ice-sheet margin zone (eastern Poland): Genesis and sedimentary record. Geomorphology 2012, 161, 73-81. [CrossRef]

43. Widera, M. Geomorphology, Sedimentology and Origin of the Glacigenic Złota Góra Hills near Konin (Central Poland). Geol. Q. 2011, 55, 235-252.

44. Falkowska, E. Glacial Morphogenesis of Uplands of the Warta Glaciation in Poland as a Control on Heavy Metal Distribution in Deposits. Geol. Q. 2010, 53, 293-304.

45. Morawski, W. Englacial kames near Jeziorany (Warmia-western Masurian lakeland, Poland): Morphology, internal structure and origin. Sediment. Geol. 2007, 193, 47-58. [CrossRef]

46. Ber, A. O zasięgu zlodowacenia Wisły w Polsce północno-wschodniej na podstawie badań geomorfologicznych i termoluminescencyjnych (w odpowiedzi H. Banaszukowi). Pol. Geogr. Rev. 2002, 74, 243-248.

47. Banaszuk, H. W odpowiedzi Andrzejowi Berowi. Pol. Geogr. Rev. 2002, 74, 255-264.

48. Żurek, S. Uwagi na temat zasięgu zlodowacenia Wisły w Polsce północno-wschodniej w związku z artykułem H.Banaszuka. Pol. Geogr. Rev. 2002, 74, 265.

49. Majewska, A. Detailed Geological Map of Poland 1:50,000; Sheet 226 Nowy Dwór; PGI: Warszawa, Poland, 2007. 
50. Woronko, B.; Rychel, J.; Karasiewicz, T.M.; Kupryjanowicz, M.; Adamczyk, A.; Fiłoc, M.; Marks, L.; Krzywicki, T.; Pochocka-Szwarc, K. Post-Saalian transformation of dry valleys in eastern Europe: An example from NE Poland. Quart. Int. 2018, 467, 161-177. [CrossRef]

51. Pavlovskaya, I.E. Late Pleistocene evolution of Hydrographical Network Recorded at Geosites in the Middle Neman Area (Western Belarus). Pol. Geol. Inst. Spec. Pap. 2004, 13, 167-174.

52. Gledko, J.A. Geomorfologiceskaya Karta 1:3 000000 (Rel'ef); Atlas Geografija Belarusi 10 kl; RUP Belkartografija: Minsk, Belarus, 2016; p. 11.

53. Lindner, L.; Sańko, A. Late Pleistocene evolution of the Niemen River valley near Grodno in Belarus. Przegląd Geol. 2008, 56, 73-80.

54. Dylik, J. Thermokarst, a neglected phenomenon in studies of the Pleistocene. Ann. Geogr. 1964, 73, 513-523. [CrossRef]

55. Edwards, M.; Grosse, G.; Jones, B.M.; McDowell, P. The evolution of a thermokarst-lake landscape: Late Quaternary permafrost degradation and stabilization in interior Alaska. Sediment. Geol. 2016, 340, 3-14. [CrossRef]

56. Stephani, E.; Drage, J.; Miller, D.; Jones, B.M.; Kanevskiy, M. Taliks, cryopegs, and permafrost dynamics related to channel migration, Colville River Delta, Alaska. Permafr. Periglac. Process. 2020, 31, 239-254. [CrossRef]

57. Dabski, M. Should Glaciers Be Considered Permafrost? Geosciences 2019, 9, 517. [CrossRef]

58. Kitover, D.C.; van Balen, R.T.; Vandenberghe, J.; Roche, D.M.; Renssen, H. LGM Permafrost Thickness and Extent in the Northern Hemisphere derived fromthe Earth System ModeliLOVECLIM. Permafr. Periglac. Process. 2016, 27, 31-42. [CrossRef]

59. Saito, K.; Sueyoshi, T.; Marchenko, S.; Romanovsky, V.; Otto-Bliesner, B.; Walsh, J.; Bigelow, N.; Hendricks, A.; Yoshikawa, K. LGM permafrost distribution: How well can the latest PMIPmulti-model ensembles perform reconstruction? Clim. Past 2013, 9, 1697-1714. [CrossRef]

60. Séjourné, A.; Costard, F.; Fedorov, A.; Gargani, J.; Skorve, J.; Massé, M.; Mège, D. Evolution of the banks of thermokarst lakes in Central Yakutia (Central Siberia) due to retrogressive thaw slump activity controlled by insolation. Geomorphology 2015, 241, 31-40. [CrossRef]

61. Bagnold, R.A. An approach to the sediment transport problem from general physics. US Geol. Surv. Prof. Pap. 1966, 422, 1-37.

62. Bull, W.B. Threshold of critical power in streams. Geol. Soc. Am. Bull. 1979, 90, 453-464. [CrossRef]

63. Wierzbicki, G.; Ostrowski, P.; Mazgajski, M.; Bujakowski, F. Using VHR multispectral remote sensing and LIDAR data to determine the geomorphological effects of overbank flow on a floodplain (the Vistula River, Poland). Geomorphology 2013, 183, 73-81. [CrossRef]

64. Dylikowa, A. Problematyka wydm śródlądowych w Polsce w świetle badań strukturalnych. Geogr. Stud. 1969, 75, 39-74.

65. Marcinkowski, P.; Grabowski, P.C.; Okruszko, T. Controls on anastomosis in lowland river systems: Towards process-based solutions to habitat conservation. Sci. Total Environ. 2017, 609, 1544-1555. [CrossRef]

66. Grygoruk, M.; Rannow, S. Mind the Gap! Lessons from science-based stakeholder dialogue in climate-adapted management of wetlands. J. Environ. Manag. 2017, 186, 108-119. [CrossRef]

(C) 2020 by the authors. Licensee MDPI, Basel, Switzerland. This article is an open access article distributed under the terms and conditions of the Creative Commons Attribution (CC BY) license (http://creativecommons.org/licenses/by/4.0/). 